\title{
PELAKSANAAN SUPERVISI AKADEMIK \\ DALAM PENINGKATKAN KOMPETENSI GURU SEKOLAH DASAR
}

\author{
Puja Ningsih \\ G-mail:pupujaningsih@gmail.com
}

\begin{abstract}
ABSTRAK
Telah dilakukan pengamatan dan survei untuk mengetahui data dan informasi pelaksanaan supervisi akademik dalam rangka meningkatkan kompetensi guru. Metode yang digunakan dalam penelitian ini adalah metode deskriptif dengan pendekatan analisis kuantitatif. Supervisi akademik merupakan pembinaan yang dilakukan yang diberikan kepada guru agar lebih profesional dalam menjalankan tugasnya dalam bidang akademik, sehingga dapat meningkatkan prestasi belajar siswa yang nantinya akan mempengaruhi mutu pendidikan di suatu lembaga pendidikan. Hasil penelitian menunjukan bahwa (1) Dinas Pendidikan serta para pengawas terlibat dalam penyusunan program supervisi akademik. (2) teknik yang digunakan bersifat umum yaitu teknik kunjungan kelas, diskui kelompok dan pembicaraan individual. Faktor pendukung pelaksanaan supervisi akademik adalah pemberian motivasi kepada guru, agar guru terdorong sehingga mau belajar dan melatih metode belajar yang lebih efektif dan efisien. Sedangkan faktor penghambat adalah alokasi waktu yang kurang dalam pelaksanaan supervisi akademik, karena banyak sekolah yang harus dibina (lebih kurang 10 sekolah), sehingga pembinaan yang dilakukan oleh pengawas terhadap guru menjadi tidak maksimal.
\end{abstract}

\section{Kata Kunci: Supervisi Akademik dan Kompetensi Guru}

\section{LATAR BELAKANG}

Perkembangan ilmu pengetahuan dan teknologi di Indonesia semakin meningkat yang menutut lembaga pendidikan agar dapat menghasilan lulusanlulusan yang dapat menyeusuaikan dengan perkembangan zaman. Personil sekolah yang kurang memadai, menjadi perhatian khusus bagi setiap lembaga pendidikan. Diantara personil yang ada, guru merupakan jajaran terdepan dalam menentukan kualitas pendidikan. Guru setiap hari bertatap muka dengan siswa dalam proses pembelajaran. Karena itu guru yang berkualitas sangat dibutuhkan oleh setiap sekolah.

Peningkatan kualitas pendidikan di sekolah memerlukan pendidikan profesional dan sistematis dalam mencapai sasarannya. Efektivitas kegiatan pendidikan di suatu lembaga pendidikan ditentukan oleh sistem pendidikan, sumber daya yang ada baik SDM, SDA dll serta dengan siswa itu sendiri, yang perlu mendapatkan pembinaan dan pengembangan secara berkelanjutan. Proses pembinaan dan pengembangan keseluruhan situasi merupakan kajian supervisi pendidikan. Dalam (sabandi, 2013) supervisor memegang peranan penting dalam meningkatkan kualitas guru agar dapat melaksanakan pembelajaran yang lebih 
berkualitas, dimana jabatan supervisor di sekolah meliputi kepala sekolah dan pengawas.

Sedangkan supervisi akademik merupakan kegiatan yang berupaya membantu guru dalam mengembangkan kemampuannya dalam mengelola proses pembelajaran untuk mencapai tujuan pendidikan. Supervisi akademik berperan penting dalam peningkatan kompetensi guru sekolah dasar. Dimana guru yang berada ditingkat SD perlu di supervisi untuk mengetahui kelemahan sehingga dapat dicari alternatif dari kelemahan atau permasalahan yang terjadi di lembaga pendidikan tingkat SD.

Berdasarkan latar belakang tersebut, maka dirumuskan masalah (1) bagaimana cara pelaksanaan supervisi akademik untuk meningkatkan kompetensi guru SD? (2) apa saja hambatan yang mungkin terjadi dan cara bagaimana solusinya terkait dengan pelaksanaan supervisi akademik pada guru SD? Tujuan tulisan ini adalah untuk mengetahui cara pelaksanaan supervisi akademik untuk meningkatkan kompetensi guru SD dan hambatan yang mungkin terjadi serta solusinya.

\section{PEMBAHASAN}

\section{Bagaimana cara pelaksanaan supervisi akademik untuk meningkatkan kompetensi guru SD?}

Pelaksanaan supervisi akademik di awali dengan memeriksa kelengkapan administrasi perangkat pembelajaran yang telah di persiapkan dan akan digunakan oleh guru dalam proses pembelajaran. Adapun perangkat pembelajaran yang di lihat adalah seperti standar pengelolaan yang meliputi program tahunan, program semester, batas mingguan, silabus, RPP, KKM, daftar nilai, buku eavaluasi dan analisis evaluasi, buku bank soal, buku perbaikan dan pengayaan, buku bimbingan siswa (konseling), jadwal pelajaran, kelender pendidikan. (Fahmi, 2018)

Dalam pelaksanaannya, dapat dilakukan secara langsung maupun tidak langsung untuk memabantu guru mengembangkan kemampuannya dalam mengelola proses pembelajaran untuk mencapai tujuan pendidikan.

Beberapa cara yang dapat dilakukan dalam pelaksanaan supervisi akademik agar meningkatnya kompetensi atau kemampuan guru SD: (1) Melakukan survei terhadap apa yang menjadi kendala guru dalam dalam mengembangkan kemampuanya mengelola kelas, (2) menjelaskan standar pengajar/ guru di tingkat SD agar mampu meningkatkan keprofesionalan guru yang nantinya dapat meningkatkan prestasi belajar siswa SD, (3) melakukan pembinaan secara bertahap dan berkesinambungan, (4) melakukan evaluasi terhadap kompetensi akademik guru, (5) mencari solusi untuk mengatasi permasalahan keprofesionaln guru.

\section{Apa saja hambatan yang mungkin terjadi dan cara bagaimana solusinya terkait dengan pelaksanaan supervisi akademik pada guru SD}

Faktor penghambat yang mungkin terjadi adalah (1) sistem kerja yang sentralisasi yang masih melekat, (2) guru dituntut untuk membiasakan budaya kerja 
baru dalam peningkatan kreativitas dan kerja keras, (3) pengalokasian waktu yang sikat dalam pelaksanaan supervisi akademik, (4) terlalu banyaknya skolah yang diawasi oleh satu pengawas sehingga pengawasan atau supervisi akademik yang diberikan tidak terlaksana secara maksimal, (5) selain itu kurangnya ketersedian dana dan sarana prasarana menjadi penghambat untuk meningkatkan kompetensi akademik guru.

Sedangkan alternatif yang dapat dilakukan dalam mengatasi beberapa permasalahan diatas adalah (1) seharusnya apa yang menjadi kebijakan sekolah tidak dicampur tangan oleh pemerintah agar sekolah lebih leluasa dala mengembangkan kreativitas dan kompetensi akademik guru dalam mengelola kelas, (2) guru harus mampu membiasakan diri dengan budaya kerja yang baru sehingga dapat dengan mudah meningkatkan kemampuan dalam mengajar sehingga dapat meniingkatkan prestasi siswa, (3) pengawas dan guru harus dapat memanfaatkan waktu yang tersedia semaksimal mungkin agar pelaksanaan supervisi akademik berjalan secar efektif dan efisien, (4) guru harus mampu memaksmalkan hasil supervisi yang diperoleh dan mengakji ulang serta mempraktekkannya agar guru lebih memahami cara pengellaan kelas yang menggambarkan keprofesionalan, (5) pemerintah dan sekolah menyediakan dana yang cukup dan penyediaan sarana dan prasarana yang memadai untuk menunjang proses pembelajaran, sehingga guru dapat mengelola kelas semaksimal mungkin sehingga dapat meningkatkan prestasi akademik siswa dan tujuan akhir dari pendidikan tercapai.

\section{KESIMPULAN}

Supervisi akademik adalah salah satu program yang dilakukan pengawas untuk meningkatkan kemampuan kompetensi guru SD. Dimana supervisi akademik merupakan kegiatan yang berupaya membantu guru dalam mengembangkan kemampuannya dalam mengelola proses pembelajaran untuk mencapai tujuan pendidikan. Supervisi akademik berperan penting dalam peningkatan kompetensi guru sekolah dasar. Dimana guru yang berada ditingkat SD perlu di supervisi untuk mengetahui kelemahan sehingga dapat dicari alternatif dari kelemahan atau permasalahan yang terjadi di lembaga pendidikan tingkat SD, yang diharapkan dapat meningkatkan prestasi belajar siswa untuk mencapai tujuan pendidikan.

\section{Referensi}

Fahmi, cut nurul. dk. (2018). PELAKSANAAN SUPERVISI AKADEMIK DALAM PENINGKATKAN KOMPETENSI GURU SEKOLAH DASAR. Serambi I/mu, Journal of Scientific Informattion and Educational Creativity, 19(2), 104-118. Retrieved from http://ojs.serambimekkah.ac.id/index.php/serambi-ilmu/article/view/1004 sabandi, ahmad. (2013). SUPERVISI PENDIDIKAN UNTUK PENGEMBANGAN PROFESIONALITAS GURU BERKELANJUTAN. Pedagogi, Jurnal IImiah IImu Pendidikan, XII/(2), 1-9. Retrieved from http://ejournal.unp.ac.id/index.php/pedagogi/article/view/4275 